\title{
伝播性破壊確率モデルと地震の震源スペクトル
}

\author{
東北大学理学部地球物理学教室 小 山 順 二 \\ (昭和 58 年 1 月 31 日受理)

\section{Earthquake Source Spectrum from Coherent and Incoherent Rupture on a Fault}

\author{
Junji Koyama \\ Geophysical Institute, Faculty of Science \\ Tohoku University
}

(Received January 31, 1983)

\begin{abstract}
Theoretical study has been made to investigate earthquake source spectrum considering coherent and incoherent ruptures on a fault. An earthquake is modeled by a propagating rupture on a fault with randomly distributed fault irregularities; fault patches. Dislocation velocity of such a fracture is assumed to be approximated by a stochastic process of random impacts of particles obeying Brownian motion. The parameters of the present source model are seismic moment, fault dimension, intensity of fault patches, and their average size. The model predicts two corner frequencies; one originates from the fault finiteness and the other from the size of fault patches. Seismic source spectrum from the model shows distinct frequency dependence of $\omega^{0}-\omega^{-2}-\omega^{-1}-\omega^{-2}$. Short-period spectrum increases in proportion to the intensity of fault paches multiplied by square root of their number. A prospect of scaling law of fault patches is also presented being based on the data available at present.
\end{abstract}

\section{§1. はじめに}

長周期地震計による観測から, 地震の大きさが, 地震マグニチュードばかりではなく, 物理的 意味のはつきりとした地震モーメントでも評価されるようになつてきた．さらに，地震の招こ り方を物理的なパラメータで記述しょうとする長周期地震学が生まれ, 遠方近似や長波長近似 の手法を用いて地震の規模や発生過程が調べられて来た[例えば，KANAMORI and ANDERSON (1975) ]. その結果, 地震断層の長さ, 幅, 〈い違い量, 破壊速度と云つた地震を表現する基 本的な物理量が明らかにされた。

一方, 我々は, 大地震の度毎に地震動による炎害を経験している. 地震動災害に直接関与す る地震波はその周期が数秒よりも短かい，短周期の地震波である.これら短周期地震波は, 長 周期地震学から導かれる決定論的な地震断層に依るものよりはるかに大きなエネルギー密度を 持つことが近年定量的に明らかにされた [KoYAMA et al. (1979); UMEDA (1981) ; IzUTANI (1981)]. 
短周期地震波の励起の問題は地震工学や災害科学の観点からも大変重要である. 更にこう云 つた波動は長周期近似では知ることの出来ない詳細な地震発生過程の情報を非常に多くもつて いることは言うまでもない。

地震学的手法を用いて短周期地震波の励起を考光るには，現在 2 通りの方法がある。その 1 は HARTZELL (1978) にならい，小さい地震を仮想断層面上で重ね合わせ大地震が励起する短 周期地震波を評価しょうとする現実的な方法である [KANAMORI (1979); 三雲・村松 (1981)； 村松・入倉 (1982) ]. その 2 は断層面上での破壊過程が規則的になめらかなものではなく，断 層面上の強度分布あるいは応力降下量が一様でない場合の地震波の励起を計算機を用いてシュ ミレーションする方法である [MIKUMo \& MiYATAKE (1978)；平沢 (1978)；ANDREWS (1981) ]. 第 1 の方法では, 長周期地震学から予測される地震の規模と短周期地震波から計る 地震の規模にどう云う物理的意味付けがあるのか明確ではないようだ。また第 2 の方法は，極 端な例として短周期地震波の励起は決定論的な地震規模には依らず断層面上の応力降下の不規 則性によつてのみ決つてしまう場合もある.

本研究では長周期地震学から示される地震の規模とその地震が励起する短周期地震波の大き さの関係を調べ，それを支配する地震発生過程について考光ることにする.

\section{§2. くい違い速度函数とその自己共分散}

ここで考觉る地震発生のモデルは次に述べる 2 つ意味で確率論的モデルである．まず，長 さ $L$ と幅 $W$ で表わされる 2 次元の断層面を考光る.ここでは断層面上でのくい違い函数 $D(\xi, t)$ を明確にするのではなく，くい違い速度函数の自己相関函数 (Autocorrelation function：Acf）から出発する．次に破壊はスムーズに拡がるが，断層面上に無数の不均質領域を 考え，断層面上の応力降下量が一様でないことをモデル化する.

HASKELL (1966) やAKI (1967) はここで考㝋ているモデルと同様にくい違い函数の自己相 関函数から地震の震源スペクトルを導びいている.しかし，彼らはいろいろな数多くの地震を 考え，それらの地震のすべり函数の期待值として Acf を取り扱つている. 本研究では 1 つの 地震発生過程が決定論的に記述できる断層破壊と不規則な小破壊の重ね合わせで表現されると 考光，その為くい違い函数の Acf を考えている。この観点の違いは，以下の地震々源スペク トルを考える上で重要である.

AKI (1967) 飞従つて断層面上でのくい違い函数 $D(\xi, t)$ を導入する. 断層は $\xi$ 軸方向に拡 がるものとし， $D(\xi, t)$ は断層の幅方向で平均したくい違い函数であるとする．断層のまわり は等方均質の無限媒質を考劣る.さらに断層破壊のはじまる点を座標原点にとり， $\xi=L$ まで 破壊が拡がるとする．震源から充分遠方で，このくい違いを生ずるせん断破壊から放出される $\mathrm{P}$ 波や $\mathrm{S}$ 波の変位波形は，断層の幅を $W$ とすると，一般に次のように表わせる

$$
u_{c}(\boldsymbol{x}, t)=T(r, \boldsymbol{n}, c) \cdot W \int_{0}^{L} \dot{D}(\xi, t-r / c) d \xi .
$$

ここで $\dot{D}$ はくい違い速度函数, $\boldsymbol{x}$ は観測点の位置, $r$ は震源 $\xi$ と の距離, $\boldsymbol{n}$ はくい違い の向きから取つた観測点の方向余弦, $c$ は $\mathrm{P}$ 波か $\mathrm{S}$ 波速度である. 函数 $T$ は断層運動の方 向をのぞけば，波の伝播系による項と考兄られる（1）式の Fourier 変換は 


$$
\begin{aligned}
& \hat{u}_{c}(\omega)=T \cdot \hat{A}(\omega), \\
& \hat{A}(\omega)=W \int_{-\infty}^{\infty} \mathrm{e}^{-i \omega t} d t \int_{0}^{L} \dot{D}(\xi, \mathrm{t}-r / c) d \xi,
\end{aligned}
$$

となる．震源スペクトル $\hat{A}(\omega)$ をこれからは，伝播系の影響と分離して考えていくことにする.

くい違い速度函数の自己相関函数 (Acf)， $\phi(\eta, \tau)$ ，を次のように定義する.

$$
\phi(\eta, \tau)=\iint_{-\infty}^{\infty} \dot{D}(\xi, t) \dot{D}(\xi+\eta, t+\tau) d \xi d t .
$$

(4) 式の Fourier 変換は

$$
\Phi(k, \omega)=\iint_{-\infty}^{\infty} \phi(\eta, \tau) \mathrm{e}^{-i \omega \eta+i k \eta} d \eta d \tau
$$

となる。AKI（1967）によれば，(3) 式の変位スペクトルと（5) 式は，

$$
|\hat{A}(\omega)|^{2}=W^{2} \Phi(k, \omega),
$$

の関係にある. 以上震源スペクトル $|\hat{A}(\omega)|$ はくい違い速度函数の Acf で表現できることを示 した。（6）式は簡単のため一方向に拡がる破壊を仮定して導びかれているが，本来どの様な破 壞のパターンであつても成立することは容易に理解出来る.

断層面上のくい違い函数 $D(\xi, t)$ は， $t \leqq 0$ でゼロ，t》1 で $D_{0}$ （定数）である. むしすべり がスムーズなら $\dot{D}(\xi, t)$ は定数で Fig. 1(a) の様に表わせる. またすべりが断層面上に分布す る不均質領域（以下断層パッチと呼ぶ）の影響で非常にぎくしやくしたものであれば， $\dot{D}(\xi, t)$ は Fig. 1(b) の様に近似されるだろう。この様な $\dot{D}(\xi, t)$ に対応する例はブラウン運動に従が ら確率衝突過程として知られている [BENDAT (1958)]. もちろんこの様な不規則変動に対応
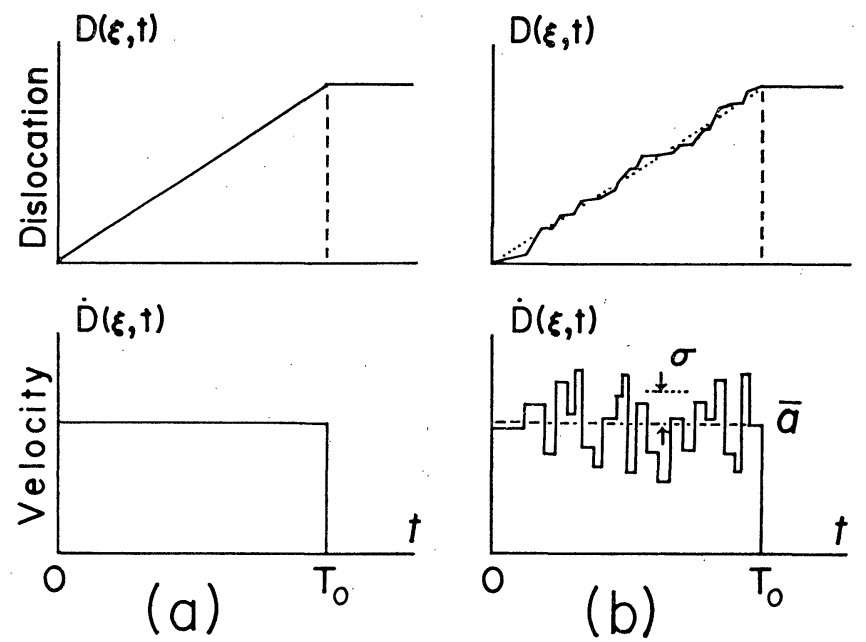

Fig. 1. Dislocation time-function and dislocation velocity time-function at a given point $\xi$ on a fault. (a) Coherent rupture. (b) Coherent and incoherent rupture. 
する他の物理過程を考えることも出来る. またくい違い速度函数をもう 1 回時間微分して加速 度時系列を統計力学的に取り扱ら立場もある. ここではくい違い速度函数のぎくしやくに注目 し，その定式化をブラウン運動の理論で考劣ることにしょう.

まず (4) 式の Acf を評価するのであるが，今考光ている時系列 $\dot{D}(\xi, t)$ は一時的な变動 現象を表現するものであり，確率論的に取り扱われる定常時系列ではないことに注意する。こ の難点は次の様に考えることにする：長周期地震学の結果は Fig. 1 で示した時間 $T_{0}$ が $W / \bar{v}(\bar{v}$ は平均的な破壊伝播速度) に関係した量であることを示している [KANAMORI and ANDERSON (1975)]. 〈い違い速度 $\dot{D}(\xi, t)$ のぎくしやくは，断層パッチに依るものであるか ら, Fig. 1(b) のパルス幅は $d / \bar{v}$ に関係する量であることがわかる（ただし $d$ は断層パッチ の特徵的長さである). 断層パッチが数多く断層面上に分布しているとすれば，その平均值を 用いて $\bar{d} / \bar{v}$ が平均的パルス幅である。もし $W / \bar{v} \gg \bar{d} / \bar{v}$ なら， $\bar{d} / \bar{v} よ り$ 長い時間スケールでは $\dot{D}(\xi, t)$ は定常であると考光て良いだろら。なぜなら数多くの断層パッチに依るパルス群が $\dot{D}(\xi, t)$ を構成しているからである. もちろん $\dot{D}(\xi, t)$ は有限であるから $W / \bar{v}$ 程度の時間スケ ールではこの限りではない.

今, 時刻によって変化する確率変数 $x(t)$ を考光る. Fig. 1(b) のような階段状の変化は, $n$ 番目の時刻 $t_{n}$ と $n+1$ 番目の時刻 $t_{n+1}$ で

$$
x(t)=a_{n}, \quad t_{n}<t<t_{n+1},
$$

で表わせる.ただし $a_{n}$ は定数である. $\left\{a_{1}, a_{2}, \cdots, a_{n}, \cdots\right\}$ は互いに独立な確率変数である. その平均と自乗平均を

$$
\begin{aligned}
& E[x(t)]=E\left[a_{n}\right]=\bar{a}, \\
& E\left[x^{2}(t)\right]=E\left[a_{n}^{2}\right]=\bar{a}^{2},
\end{aligned}
$$

と拈く.

BENDAT (1958)によれば, 次の様にして (7) 式の自己共分散函数 (Autocovariance function: Acvf), $R_{x x}\left(t_{1}, t_{2}\right)$, が計算される. 今確率衝突過程が Poisson 分布に従らとすると, $x\left(t_{1}\right)$ と $x\left(t_{2}\right)$ が同じ時間区間に抢ける確率 $P$ は

$$
P=\mathrm{e}^{-\lambda\left|t_{2}-t_{1}\right|},
$$

であるたただし入は単位時間あたりの平均衝突回数である. 従つて $x\left(t_{1}\right)$ と $x\left(t_{2}\right)$ が同じ区間 にない確率 $P^{*}$ は

$$
P^{*}=1-\mathrm{e}^{-\lambda\left|t_{2}-t_{1}\right|},
$$

となる. 従つて $x(t)$ の Acf は $\tau=t_{2}-t_{1}$ とすれば

$$
\begin{aligned}
R_{x x}(\tau) & =E\left[x\left(t_{1}\right) x\left(t_{2}\right)\right] \\
& =P \cdot E\left[x\left(t_{1}\right) x\left(t_{2}\right) \mid P\right]+P^{*} E\left[x\left(t_{1}\right) x\left(t_{2}\right) \mid P^{*}\right],
\end{aligned}
$$

となる.ここで $E\left[x\left(t_{1}\right) x\left(t_{2}\right) \mid P\right]$ や $E\left[x\left(t_{1}\right) x\left(t_{2}\right) \mid P^{*}\right]$ はそれぞれの条件下での条件付期待値と 考える：すなわち

$$
\begin{aligned}
& E\left[x\left(t_{1}\right) x\left(t_{2}\right) \mid P\right]=E\left[x^{2}(t)\right]=\bar{a}^{2}, \\
& E\left[x\left(t_{1}\right) x\left(t_{2}\right) \mid P^{*}\right]=E\left[x\left(t_{1}\right)\right] E\left[x\left(t_{2}\right)\right]=\bar{a}^{2},
\end{aligned}
$$


である.よつて

$$
R_{x x}(\tau)=\bar{a}^{2}+\sigma^{2} \exp (-\lambda|\tau|)
$$

$\sigma^{2}$ は平均值 $\bar{a}$ の分散である.

(15) 式で与えられた Acf は無限に長い時系列から求まるものであり, 実際上は, 有限な長 さの時系列から計算される Acf の推定值 $C_{x x}(\tau)$ を用いる. 有限な長さ $T_{0}$ の $k$ 番目のレコ ードの Acf を $C_{x x}^{k}(\tau)$ と抏くと,

$$
C_{x x}^{k}(\tau)= \begin{cases}\frac{1}{T_{0}} \int_{0}^{T_{0}-|\tau|} x_{k}(t) x_{k}(t+|\tau|) d t, & 0 \leqq|\tau| \leqq T_{0}, \\ 0, & |\tau|>T_{0},\end{cases}
$$

である. $T_{0} \rightarrow \infty$ の時, $C_{x x}^{k}(\tau) \rightarrow R_{x x}(\tau)$ である. いろいろな $k$ の Acf の推定值から, その平 均を計算する：

$$
E\left[C_{x x}^{k}(\tau)\right]=\frac{1}{T_{0}} E\left[\int_{0}^{T_{0}-|\tau|} x_{k}(t) x_{k}(t+|\tau|) d t\right]
$$

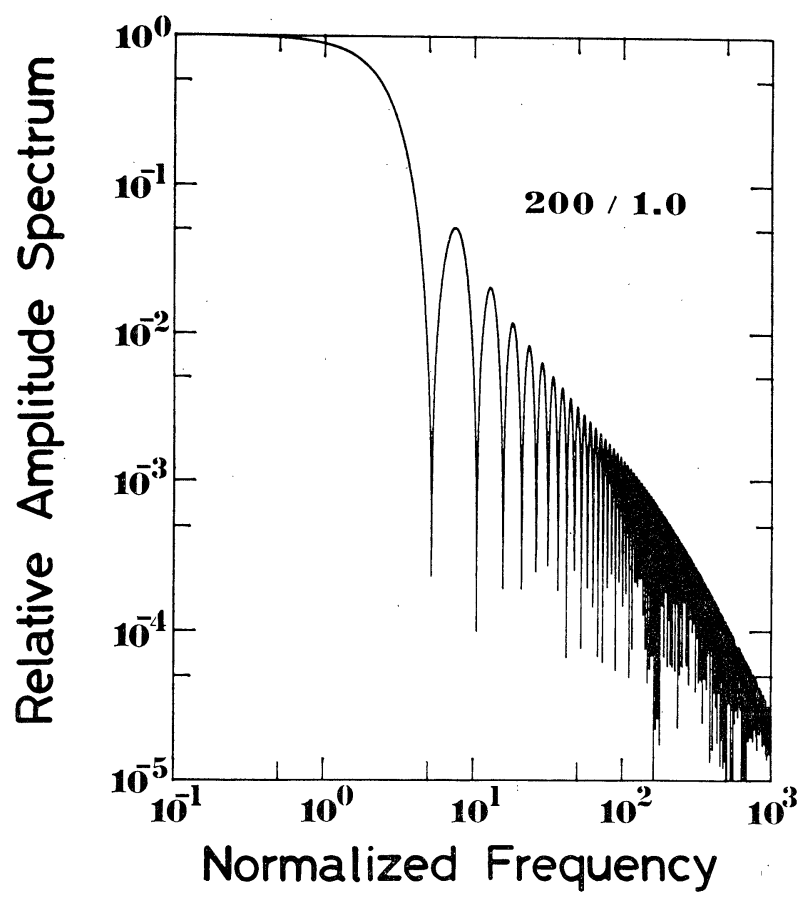

Fig. 2. Normalized source spectrum of the coherent and incoherent rupture as a function of normalized frequency $\eta$ in eq. (25). The parameters of this earthquake source are; unit seismic moment, normalized rise time $\tau$ in eq. (25) is about 1.2, normalized patch shortness $\zeta$ is 200 , and intensity of fault patches, $\sigma^{2} / \bar{a}^{2}$, is 1.0 . The spectrum is calculated in a equal interval on the logarithmic scale and plotted by a computer, so that, the spectral troughes in the figure are not correctly illustrated. They all should be infinitely small. 


$$
= \begin{cases}\left(1-\frac{|\tau|}{T_{0}}\right) R_{x x}(\tau), & 0 \leqq|\tau| \leqq T_{0}, \\ 0, & |\tau|>T_{0} .\end{cases}
$$

(17) 式は時系列 $x(t)$ がエルゴード性を満足すれば，成立する.

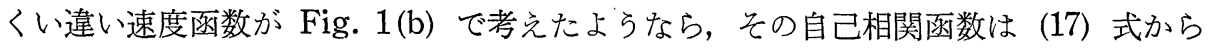

$$
\frac{1}{T_{0}} \int_{-\infty}^{\infty} \dot{D}(\xi, t) \dot{D}(\xi, t+\tau) d t= \begin{cases}\left(1-\frac{|\tau|}{T_{0}}\right)\left\{\bar{a}^{2}+\sigma^{2} \exp (-\lambda|\tau|)\right\}, & 0 \leqq|\tau| \leqq T_{0} \\ 0, & |\tau|>T_{0}\end{cases}
$$

と表わせる. 有限な長さのデータから得られた自己相関函数は（18）式のようにバートレット 型の重みが付いたものがその不偏推定值である [JENKINS and WATTS, (1968)]. 物理的には振 幅が 1 で有限時間 $T_{0}$ のパルス幅をもつ boxcar 函数を 2 つ考光, そのたたみ込みを重みと していることを示している.つまり時間軸上で $t=0$ から $t=T_{0}$ までシグナルが存在し， $t<0$, $t>T_{0}$ はゼ口である時系列の取り扱いである. 空間的に断層は $\xi=0$ から $\xi=L$ の間に存在し, 他にはない. (4) 式で考えた自己相関函数を計算する時, 空間的拡がりの相関関係も同様に考 党，破壞の先端が伝播することを考慮すれば，(4) 式は（18）式を用いて

$$
\begin{aligned}
& \iint_{-\infty}^{\infty} \dot{D}(\xi, t) \dot{D}(\xi+\eta, t+\tau) d \xi d t \\
& = \begin{cases}L T_{0}\left(1-\frac{|\eta|}{L}\right)\left(1-\frac{|\tau-\eta| \bar{v} \mid}{T_{0}}\right)\left\{\bar{a}^{2}+\sigma^{2} \exp (-\lambda|\tau-\eta| \bar{v} \mid)\right\}, & |\eta| \leqq L \text { and }|\tau-\eta| \bar{v} \mid \leqq T_{0}, \\
0, & \text { otherwise . }\end{cases}
\end{aligned}
$$

と表わせるだろう。

\section{§3． 伝播性破壊確率モデル}

階段状にぎくしやくした断層面上のくい違い速度函数が，(19) 式で表わされる自己相関函数 を持つことがわかつた. BOORE \& JOYNER (1978) を参照して (5) 式の Fourier 変換をする と, $W \gg \bar{d}$ のとき,

$$
\begin{aligned}
|\hat{A}(\omega)|^{2} / W^{2} L^{2} T_{0}{ }^{2} & \\
= & \bar{a}^{2} \frac{\sin ^{2}\left(\omega T_{0} / 2\right)}{\left(\omega T_{0} / 2\right)^{2}} \frac{\sin ^{2}\{(k-\omega / \bar{v}) L / 2\}}{\{(k-\omega / \bar{v}) L / 2\}^{2}} \\
& +\frac{2 \sigma^{2}}{T_{0}{ }^{2}} \frac{\left.\sin ^{2}\{k-\omega / \bar{v}) L / 2\right\}}{\{(k-\omega / \bar{v}) L / 2\}^{2}}\left[\frac{\omega^{2}-\lambda^{2}}{\left(\omega^{2}+\lambda^{2}\right)^{2}}+\frac{\lambda T_{0}}{\omega^{2}+\lambda^{2}}\right],
\end{aligned}
$$

を得る。(20) 式中の $k$ は波数であり，ここでは $\omega \cos \theta / c$ である.ただし $\theta$ は破壊の先端が 進さ方向と観測点がなす角度である. 簡単のため断層面に垂直な方向 $(\theta=\pi / 2)$ に放出される波 の震源スペクトル $|\hat{A}(\omega)|$ を考学よう. (20) 式右辺第 1 項は断層の幾可学的拡がりによるコ 一ナ周波数 $1 / \pi(W / \bar{v})$ と $1 / \pi(L / \bar{v})$ をもつ平均的な破壊に伴ら寄与であることがわかる. 同じく 第 2 項は $1 / \pi(L / \bar{v})$ と $1 / 2 \pi(\bar{d} / \bar{v})$ がコーナ周波数となる不均質領域 (断層パッチ) の破壊に伴う 震源スペクトルを表わしている.

低周波数での (20) 式の振るまいを調べてみよう. 右辺第一項は $\omega \rightarrow 0$ のとき平均的なくい 
違い量の断層面全体での和を示す定数值に近づく；すなわら

$$
\left\{W L T_{0} \bar{a}\right\}^{2}=\left\{\iint_{\Sigma} d \Sigma \int_{0}^{T_{0}} E[\dot{D}(\xi, t)] d t\right\}^{2},
$$

ただし $\Sigma$ は断層面全体を示し，ここでは $W \times L ，$ 考光れば良い（21）式右辺は地震モーメ ントに直接関係する量である [AKI and RICHARD (1980)]. (20) 式右辺第 2 項は $\omega \rightarrow 0$ のと き $\left(W L T_{0} \sigma \sqrt{2 / \lambda T_{0}}\right)^{2}$ に漸近する. ただし $W \gg \bar{d}$ の仮定から $\lambda T_{0} \gg 1$ として近似してある.

したがつて，このモデルでは平均的な地震モーメントの大きさと不均質領域による寄与が低 周波での震源スペクトル構造を規定する. それらの比が

$$
\left(W L T_{0}\right)^{2} \bar{a}^{2} /\left(W L T_{0}\right)^{2} \sigma^{2} \frac{2}{\lambda T_{0}}=\frac{\lambda T_{0} \bar{a}^{2}}{2 \sigma^{2}} \gg 1,
$$

上式を満足すると, 地震モーメント（長周期地震波の励起）は断層面上の平均的なすべりで決 まり，不均質性の寄与は小さいことを意味する．今 $L=W$ とすると $T_{0}$ は $W / \bar{v}$ 程度である ことが知られている[例えば KANAMORI and ANDERSON (1975)]. 平均衝突回数 $\lambda$ は同様に して $\bar{v} / \bar{d}$ 程度であることが期待される. したがって， $\lambda T_{0}$ は凡と $W / \bar{d}$ ，つまり断層の幅程度 の長さに不均質領域が何個，平均的に入るかに対応する.

$\omega=\lambda$ の短周期では，今度は逆に不均質性の寄与が平均的なすべりよりはるかに大きいこと が期待される;

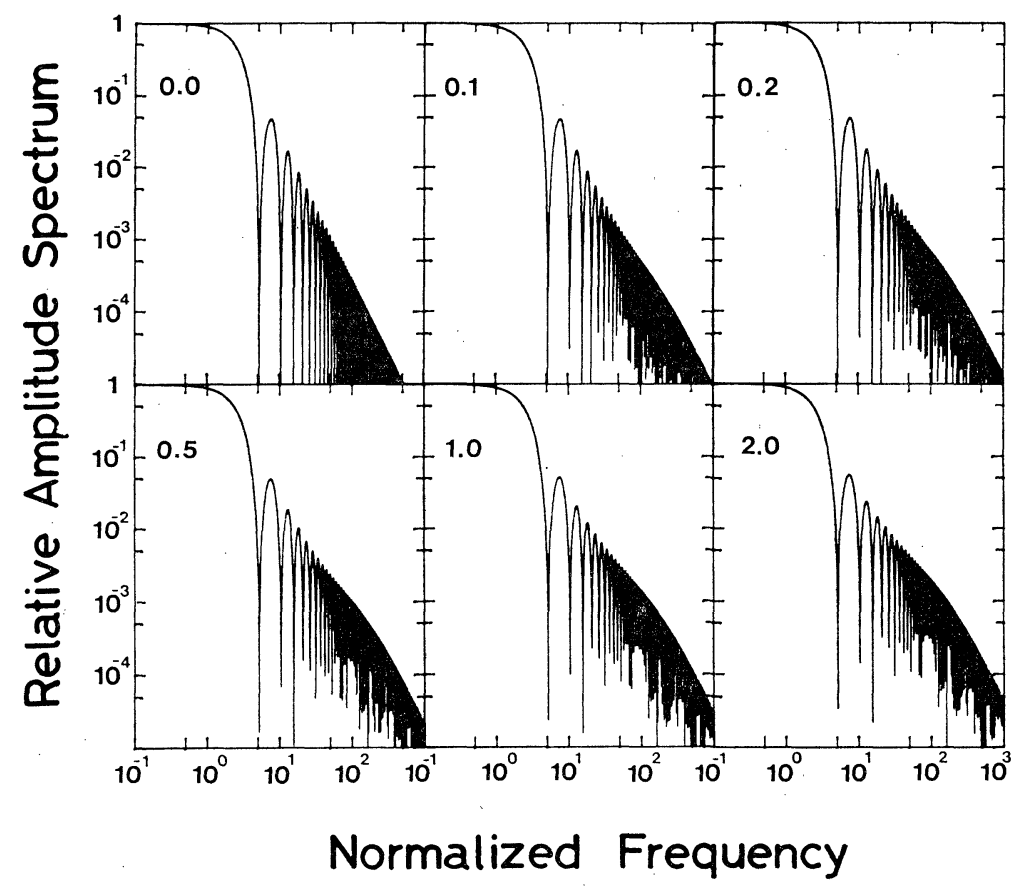

Fig. 3. Source spectra as a function of normalized frequency with different intensity of fault patches, $\sigma^{2} / \bar{a}^{2}=0.0,0.1,0.2,0.5,1.0$, and 2.0 , in case of $\zeta=200$. Other parameters are the same as those in Fig. 2. 


$$
\frac{2 \sigma^{2}}{T_{0}^{2}}\left[\frac{\lambda T_{0}}{2 \lambda^{2}}\right] \gg \bar{a}^{2} \frac{\sin ^{2}\left(\lambda T_{0} / 2\right)}{\left(\lambda T_{0} / 2\right)^{2}} .
$$

(22)，（23）式からくい違い速度の分散で表現される断層の不均質性は

$$
\frac{4}{\lambda T_{0}} \ll \frac{\sigma^{2}}{\bar{a}^{2}} \ll \frac{\lambda T_{0}}{2},
$$

となる. 左の不等式は短周期エネルギーの增加は $\lambda T_{0} \sigma^{2}$ に比例することを示し, 右のそれはく い違い速度のゆらぎが極端に大きくなり得ないことを示している。

(20) 式のエネルギースペクトルの平方根は震源変位スペクトルである. 明らかに $\omega>\lambda$ の 短周期帯では, $|\hat{A}(\omega)| \sim \omega^{-2}$ であることがわかる. したがつてこの震源モデルの総エネルギー は有限である。

\section{$\S 4$. 結 論}

伝播性破壊確率モデルと名付けた前章の震源モデルは 1) 地震モーメント，2）断層の幅や 長さ，3）不均質性の大きさ，4）不均質性の平均的長さの 4 つのパラメータで表現される. 前 2 者は従来考えられてきた長周期地震学から記述される震源パラメータであり, 後 2 者は断層 の不均質性を表わすパラメータで短周期地震波の励起に深くかかわつている.

(20) 式を次の様に近似，規格化する：

$$
\begin{aligned}
& T_{0}=W / \bar{v}=L / \bar{v}, \\
& \tau=T_{0} /(W / \beta), \quad \text { (normalized rise time), } \\
& \eta=\omega(W / \beta), \quad \text { (normalized frequency), } \\
& \zeta=\lambda(W / \beta), \quad \text { (patch shortness), } \\
& \frac{|\hat{A}(\eta)|}{\left(W L T_{0}\right) \bar{a}}=\frac{|\sin \eta \tau / 2|}{\eta \tau / 2}\left[\left\{\frac{\sin \eta \tau / 2}{\eta \tau / 2}\right\}^{2}+\frac{2 \sigma^{2}}{\tau^{2} \bar{a}^{2}}\left\{\frac{\eta^{2}-\zeta^{2}}{\left(\eta^{2}+\zeta^{2}\right)^{2}}+\frac{\zeta \tau}{\eta^{2}+\zeta^{2}}\right\}\right]^{1 / 2}
\end{aligned}
$$

ただし $\beta$ は S 波速度とする．左辺は規格化された震源スペクトルとなつている，いま，平均 的破壊伝播速度を $\bar{v}=0.83 \beta$ と仮定すれば，(25) 式の $\tau$ は約 1.2 となる.Fig. 2 は規格化さ れた角周波数 クを軸に取り， $\sigma^{2} / \bar{a}^{2}=1 ， \zeta=200$ の時の震源スペクトルを示す. クが約 1.7 と 200 にスペクトルの折れふがりが見い出せる。この角周波数は，それぞれ，断層全体の有限性 と断層面上の不均質領域の平均的大ささに対応したコーナー角周波数になつている. また， ス ペクトル構造が長周期側から $\omega^{0} \rightarrow \omega^{-2} \rightarrow \omega^{-1} \rightarrow \omega^{-2}$ と周波数依存性を示すことが見て取れる. ス ペクトル構造が長周期地震学から期待される断層面全体の平均的破壊の寄与から断層面上の不 均質性の寄与へ乗り換光ることでこの周波数依存性が現われる訳である。一方，この周波数依 存性は AKI (1972) が直感的に導入した震源モデル (改良Bモデル) に一致している. SAT0 and HIRASAwA（1975） はこの改良 B モデルを断層面全体に渡る応力降下の時間的変化で物 理的に説明した. 本研究ではこのような“人工的な応力時間函数” (SATO，私信，1975）を導 入しなくとも, 震源過程の単純な考察から改良 B モデルに対応する物理的震源モデルを導く ことができた.

Fig, 3 は $\zeta=200$ のとき， $\sigma^{2} / \bar{a}^{2}$ をパラメータにしてスペクトル構造の変化を示した. 短周 期スペクトル成分は $\sqrt{\lambda T_{0}} \sigma$ に比例して増加するから， $\sigma^{2} / \bar{a}^{2}=0.5$ のスペクトル成分は $\eta=$ 


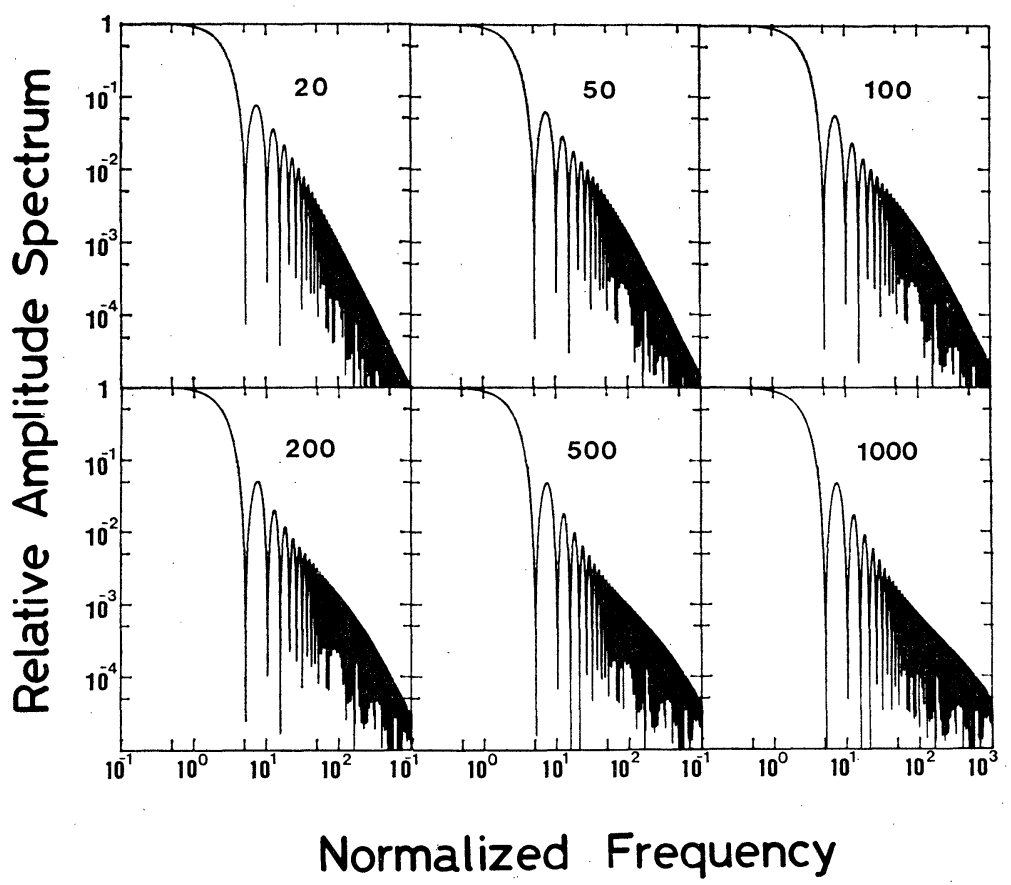

Fig. 4. Source spectra as a function of normalized frequency with different patch shortness, 20,50,100,200,500 and 1000 in case of $\sigma^{2} / \bar{a}^{2}=1.0$. Other parameters are same the as those in Fig. 2.

200 で $\sigma^{2} / \bar{a}^{2}=0.0$ のそれに比べて 10 倍， $\sigma^{2} / \bar{a}^{2}=2.0$ のスペクトル成分は $\sigma^{2} / \bar{a}^{2}=0.0$ のそれ に比べて 20 倍になつている.

現実的な観測データがないので比較すべき対象はないが，〈い違い速度の分散があまり小さ い, 平均くい違い速度の数十\%, なら短周期成分の増加はあまり顕著ではない。

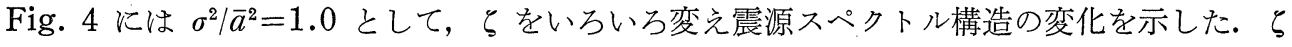
が大きくなるにつれて第 2 番目のコーナー角周波数が短周期へ移つていく様子がわかる。また スペクトル構造の $\omega^{-1}$ 依存性を示寸範囲がだんだんと拡くなつていることに気付く.

AKI (1972) は改良 B モデルのスペクトル構造に表面波マグニチュードと実体波マグニチュ ードの関係を満たすよらスケーリング関係を考学ている：しかし，最近の小山と鄭 (1982) に よる研究によれば, 最大振幅しか使わないマグニチュードスケールは震源スペクトルを測る目 安になりにくいことが指摘されている.

短周期の震源スペクトル構造を直接調べた研究は少ない，その中で IZUTANI (1981) は松代 群発地震の加速度記録から断層の不均質性によるコーナー周波数を 14 個の地震について報告 てている. Table 1 に地震モーメントが KoYAMA et al. (1979) により比較的精度良く決定 された 12 個の地震について，それらのコーナー周波数を引用した. Fig. 5 に地震モーメント と IZUTANI (1981) によるコーナー周波数を示した. 長周期地震学から決定論的に決められる コーナー周波数は地震モーメント $M_{0}=10^{25} \mathrm{dyne} \cdot \mathrm{cm}$ で $0.1 \mathrm{~Hz}, M_{0}=10^{22} \mathrm{dyne} \cdot \mathrm{cm}$ で 
Table 1. Seismic moment and corner frequency of the Matsushiro earthquakes.

\begin{tabular}{ccc}
\hline \hline $\begin{array}{c}\text { No. Matsushiro } \\
\text { Earthquake }\end{array}$ & $\begin{array}{c}\text { Seismic } \\
\text { Moment }\end{array}$ & $\begin{array}{c}\text { Corner } \\
\text { Frequency }\end{array}$ \\
\hline \multicolumn{3}{c}{ dynecm } \\
53 & \multicolumn{3}{c}{$3.0 \times 10^{23}$} & $2.1^{*}$ \\
322 & $2.8 \times 10^{23}$ & 4.4 \\
147 & $2.4 \times 10^{23}$ & 2.3 \\
262 & $2.1 \times 10^{23}$ & 3.1 \\
270 & $1.0 \times 10^{23}$ & $2.3^{*}$ \\
169 & $7.2 \times 10^{22}$ & $5.0^{*}$ \\
123 & $6.2 \times 10^{22}$ & $4.0^{*}$ \\
192 & $5.8 \times 10^{22}$ & 3.5 \\
425 & $4.7 \times 10^{22}$ & 3.6 \\
219 & $4.4 \times 10^{22}$ & $4.2^{*}$ \\
74 & $3.9 \times 10^{22}$ & 3.6 \\
95 & $3.2 \times 10^{22}$ & 4.4 \\
\hline
\end{tabular}

\# quated from IzUTani (1981).

* indicated arithmetic mean of two or more stations' data.

$1 \mathrm{~Hz}$ 程度である [AKI (1972)]. IZUTANI (1981) の值は明らかに決定論的なコーナ 一周波数とは異なることが見てとれる. 更に, $M_{0} \sim f_{c}{ }^{*-3}$ の関係があるように見 える.この種の観測事実が震源スペクト ルのスケーリング則を規定する重要な制 約条件になるのであるが，現在あるデー タは上で述べたように松代地震という， 地震規模の比較的小さい, 内陸に発生し

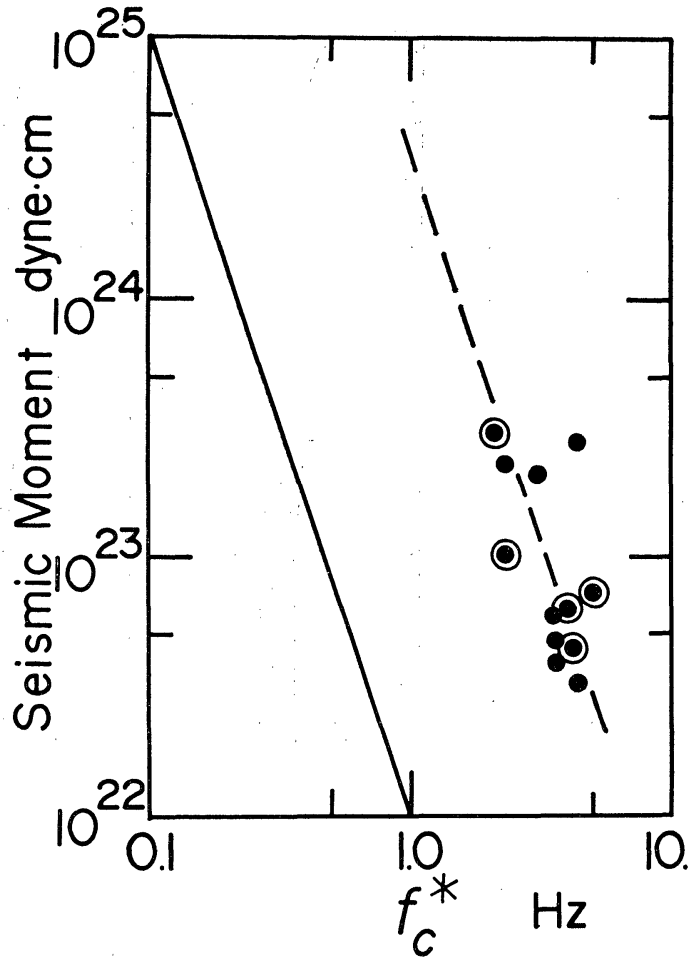

Fig. 5. Seismic moment and patch corner frequency, $f_{c}^{*}$, of the Matsushiro earthquakes in Table 1. Double circles indicate $f_{c}{ }^{*}$ estimated from two or more data. Solid line indicates the relation beween corner frequency and seismic moment by AKI (1967). Broken line shows different relation from the former.

た地震である．Fig. 5 に示した関係をそのまま島弧沿いで発生する大地震にまで外挿して良 いのか，内陸の地震とは異なつた断層の不均質性が島弧沿いの地震を支配しているのか今後の 重要な問題であると考学る。

\section{文献}

AKI, K., 1967, Scaling Law of Seismic Spectrum, J. Geophys. Res., 72, 1217-1231.

AKI, K., 1972, Scaling Law of Earthquake Source Time-Function, Geophys. J., 31, 3-25.

AKI, K. and P. G. RICHARD, 1980, Quantative Seismology Theory and Methods, Vol. 1, W. H. Freeman and Company, San Francisco, 37-121.

Andrews, D. J., 1981, A Stochastic Fault Model, 2. Time-dependent Case, J. Geophys. Res., 86, $10821-10834$.

Bendat, J. S., 1958, Principles and Applications of Random Noise Theory, Wiley \& Sons, New York, 1-215.

BOoRE, D. M. and W. B. JoYNer, 1978, The Influence of Rupture Incoherence on Seismic 
Directivity, Bull. Seism. Soc. Am., 68, 283-300.

Hartzell, S. H., 1978, Earthquake Aftershocks as Green Functions, Geophys. Res. Lett., 5, 1-4.

HASKell, N. A., 1966, Total Energy and Energy Spectral Density of Elastic Wave Radiation from Propagating Faults, 2. A Statistical Source Model, Bull. Seism. Soc. Am., 56, 125140.

平沢朋郎, 1978, 確率モデルによる最大加速度の予測, 文部省科研費報告書「地震活動度と震害分布」, $35-45$.

IzUtani, Y., 1981, A Statistical Model for Prediction of Quasi-realistic Strong Ground Motions, J. Phys. Earth, 29, 537-558.

Jenkins, G. M. and D. G. WatTs, 1968, Spectral Analysis and its Applications, Holden-Day, San Francisco, 209-248.

Kanamori, H., 1979, A Semi-empirical Approach to Prediction of Long-period Ground Motions from Great Earthquakes, Bull. Seism. Soc. Am., 69, 1645-1670.

Kanamori, H. and D. L. ANDerson, 1975, Theoretical Basis of Some Empirical Relations in Seismology, Bull. Seism. Soc. Am., 65, 1073-1095.

小山順二・鄭 斯華, 1982, 巨大地震が励起した短周期実体波, 地震学会講演予稿集, No. 2, 89.

Koyama, J., M. TAkemura and Z. Suzuki, 1979, Seismic-moment Determination Qualified for Routine Processing of Seismic Data, Sci. Rept. Tohoku Univ., Ser. 5, Geophys., 26, 81-91.

Mikumo, T. and T. Miyatake, 1978, Dynamical Rupture Process on a Three-dimensional Fault with Non-uniform Frictions, and Near-field Seismic Waves, Geophys. J., 54, 417-438.

三雲 健・村松郁栄, 1981, 大地震の断層モデルによる長周期地動変位速度の予測, 京都大学防災研究 所年報, 24, 85-104.

村松郁栄・入倉孝次郎，1982，余震または前震記録の合成による本震時の強震動の予測 (その 2), 文 部省科研費報告書「東海地方に抢ける大地震の被害予測に関する研究」33-46.

Sato, T. and T. Hirasawa, 1975, Effects, of Partial Relaxation of the Effective Stress upon Seismic Radiation, Sci. Rep., Tohoku Univ., Ser. 5, Geophys., 22, 153-165.

UmEDA, Y., 1981, An Earthquake Source Model with a Ripple Generating Core, J. Phys. Earth, 29, 341-370. 